Abstracta Iranica Abstanica

Revue bibliographique pour le domaine irano-aryen

Volume 28 | 2007

Comptes rendus des publications de 2005

\title{
«The Achaemenid Empire in South Asia and Recent Excavations in Akra in Northwest Pakistan ». AJA, 109/4, pp. 711-741.
}

\section{Astrid Nunn}

\section{(2) OpenEdition}

Journals

Édition électronique

URL : http://journals.openedition.org/abstractairanica/16052

DOI : 10.4000/abstractairanica.16052

ISSN : 1961-960X

Éditeur :

CNRS (UMR 7528 Mondes iraniens et indiens), Éditions de l'IFRI

\section{Édition imprimée}

Date de publication : 15 mai 2007

ISSN : 0240-8910

Référence électronique

Astrid Nunn, « "The Achaemenid Empire in South Asia and Recent Excavations in Akra in Northwest Pakistan ». AJA, 109/4, pp. 711-741. », Abstracta Iranica [En ligne], Volume 28 | 2007, document 102, mis en ligne le 18 septembre 2007, consulté le 25 septembre 2020. URL : http:// journals.openedition.org/abstractairanica/16052 ; DOI : https://doi.org/10.4000/abstractairanica. 16052

Ce document a été généré automatiquement le 25 septembre 2020.

Tous droits réservés 
« The Achaemenid Empire in South Asia and Recent Excavations in Akra in Northwest Pakistan ». AJA, 109/4, pp. 711-741.

\section{Astrid Nunn}

1 Trois provinces localisées aux marges orientales de l'Empire achéménide appartiennent à l'Asie du Sud (Gandara, Thataguš et Hinduš). La recherche au Pakistan qui s'intéresse depuis plus d'un siècle à l'époque achéménide manquait jusqu'à présent de sites bien stratigraphiés et l'accès à l'histoire de cette région à cette époque s'est surtout fait par de (beaux) objets. La fouille américaine à Akra, à la frontière afghane dans le nordouest du Pakistan, montre que l'annexion à l'Empire achéménide eut un impact social (mesurable à l'urbanisme) et économique plus grand qu'on ne le pensait. La ville se développa dès le début $\mathrm{du} \mathrm{I}^{\mathrm{er}}$ millénaire et entretint des contacts avec la péninsule indienne et l'Asie Centrale. Le réseau routier et sa sécurité permirent d'élargir les relations économiques. Les AA. exploitent aussi bien les sources achéménides concernant l'est - ce site était-il la capitale de Thataguš ? - que l'histoire préachéménide de Akra avec ses assemblages de céramiques et son travail du métal.

\section{INDEX}

Thèmes : 3.2.2. Pré-Achéménides et Achéménides 
AUTEURS

ASTRID NUNN

Université de Munich 